\title{
Comparison of the Infant Deaths of 2016-2017 Years
}

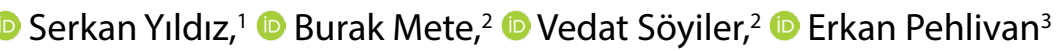 \\ ${ }^{1}$ Kayseri Provincial Directorate of Health, Kayseri, Turkey \\ ${ }^{2}$ Bingöl Provincial Directorate of Health, Bingöl, Turkey \\ ${ }^{3}$ Department of Public Health, Inonu University, Malatya, Turkey
}

\section{ABSTRACT}

Objectives: Infant mortality is closely related tothe welfare and development level of society. Primary care interventions can be effective in preventing these deaths. The present study aims to investigate the prevalence of infant mortality in Bingöl province in 2016-2017, which is one of Turkey's eastern cities, the reasons and factors that maybe related to the prevalence of infant mortality.

Methods: The type of this research is routine surveillance study. The data were collected retrospectively by examining the deaths of 99 infants in Bingöl province in 2016 and the deaths of 69 infants in 2017 through their medical record files in this study.

Results: The infant mortality rate, which was $0.18 \%$ in 2016 , decreased to $0.12 \%$ in 2017 . In 2016 , the most common cause of infant mortality was prematurity 43 (43.4\%) and congenital anomalies 35 (35.4\%). The most common cause of death in 2017 was a congenital anomaly 28 (41.7\%) and prematurity 25 (37.3\%).

Conclusion: In our study, infant mortality rates in Bingöl were higher than the national average in 2016 and 2017. Congenital anomaly and prematurity were the most common causes of infant mortality in both years. Such studies showing the causes of infant mortality and their changes over the years can be a guide for health policymakers.

Please cite this article as: Yıldız S, Mete B, Söyiler V, Pehlivan E. Comparison of the Infant Deaths of 2016-2017 Years. Anatol J Family Med 2020;3(1):17-21.

Address for correspondence: Dr. Serkan Yıldız. Kayseri Provincial Directorate of Health, Kayseri, Turkey

Phone: +90 5067170755

E-mail:

serkanyildizserkan@gmail.com

Received Date: 16.07.2019

Accepted Date: 22.12.2019

Published online: 01.04 .2020

OCopyright 2020 by Anatolian Journal of Family Medicine -

Available online at Www.anatoljfm.org

OPEN ACCESS

Keywords: Health services research, infant mortality, primary health care

\section{INTRODUCTION}

The data that were collected in the healthcare field and the analytical examination of these data are important in that this will determine the health status of the society, show whether the healthcare services provided to the society are successful or not, and reveal the problems with priority in the society. Infant mortality is a healthcare indicator that is employed to compare the development level of society and the welfare of communities. Infant mortality occurs in the first year of life. Infant mortality is closely related to social welfare and development; as welfare and development increase, infant mortality decreases ${ }^{[1]}$ In the context of the Millennium Development Goals in Turkey, the purpose is to reduce infant and child mortality by two-thirds. To achieve this purpose, it is proposed that the social status of women is raised, vaccinations should be administeredand the births should be delivered by trained healthcare staff. ${ }^{[2]}$ A reduction has been detected in Turkey in infant and children mortality in recent years. Infant mortality decreased by 24 percent between the years 2008 and 2013. ${ }^{[3]}$ Infant 
mortality occurring in the urban and western regions have decreased more. Factors, such asmaternal training, maternal age at birth, socioeconomic status, the gender of the infant, the order of birth, the time period since the previous birth and weight of the baby at birth, are effective in infant mortality. ${ }^{[3]}$ With this study, our aim to investigate the rates, causes and relevant factors of infant mortality in the 20162017 period in Bingöl province.

\section{METHOD}

The type of this research is routine surveillance study. Data were collected retrospectively by examining the deaths of 99 infants in Bingöl province in 2016 and the deaths of 69 infants in 2017 through their medical record files. The detailed data obtained on infant mortality and causes were collected by reviewing the medical record files of the infants.

The data, such as the birth dates of the infants who died, days of death, genders, birth place, birth types, pregnancy week, educational level of the mothers, first-line follow-up of the mothers, presence of familial relation between the mother and father, Rh incompatibility of the mother and father, existence of chronic illness in the mother, drug use of the mother, pregnancy story of the mother, and the level of education and work status of the father, were included in this study.

All the statistical analyses were carried out using SPSS Software. Frequency, percentage, mean, standard deviation, median, minimum and maximum values were calculated. The Chi-square test was employed in the analysis of the study data and, $p<0.05$ was considered to be significant. This study was approved by the Ethics Committee with the letter No. 23234772-929 and dated 17.12.2019 of Bingöl Provincial Health Directorate. This study was conducted in accordance with the Declaration of Helsinki.

\section{RESULTS}

In the city of Bingöl, there were a total of 5485 live births and 99 infant deaths in 2016; 5440 live births and 67 infant deaths in 2017. While the infant mortality rate for 2016 was 18 per thousand, the infant mortality rate in 2017 was calculated as 12 per thousand. The data about the 99 infants who died in 2016 were as follows: 50 (50.5\%) of the infants who died were male. A total of 69 (69.7\%) of the 99 babies was premature and 56 (56.6\%) were born with caesarean. Blood incompatibility was detected in $13(13.1 \%)$ of the infants who died; 38 (38.4\%) of the parents were familial relatives, and 36 (36.4\%) of them had congenital anomalies. For the dead infants, the data on birth weights, gestational weeks, maternal ages, and the days they died are given in Table 1.
The data on the 67 infants who died in 2017 are as follows: $29(43.2 \%)$ of the infants who died were male; $38(56.7 \%)$ of the 67 infants were born premature, and 49 (73.1\%) were born with caesarean. It was observed that in $7(10.4 \%)$ of the infants who died, there was Rh incompatibility; 15 (22.4\%) had a parental kinship, and 29 (43.3\%) had congenital anomalies. The infant mortality reasons for the years 2016 and 2017 are shown in Table 2.

It was observed that the most common cause of infant deaths in the city of Bingöl for the year 2016 was prematurity; and congenital anomaly for the year 2017. Deaths that arose from prematurity decreased.

Infant mortality rates were calculated according to 5485 live births in 2016 and 5440 live births in 2017. The Chi-square test was used to compare infant mortality rates according to periods. According to Chi-square tests, infant mortality decreased in 2017 compared to 2016. It was also observed that the decreases in early neonatal and post-neonatal periods were statistically significant, and the change in the late

\begin{tabular}{|c|c|c|}
\hline & $\begin{array}{c}2016(n=99) \\
\text { Median (Min-max) }\end{array}$ & $\begin{array}{c}2017 \text { ( } n=67 \text { ) } \\
\text { Median (Min-max) }\end{array}$ \\
\hline Birth weight (gr) & $1700.0(400.0-3700.0)$ & $2095.0(500.0-4000.0)$ \\
\hline Gestational week (we & eks) 33.0 (20.0-40.0) & $34.0(21.0-42.0)$ \\
\hline \multirow[t]{2}{*}{ Day of death (days) } & $6.0(1.0-280.0)$ & $11.0(1.0-345.0)$ \\
\hline & Mean \pm SD & Mean \pm SD \\
\hline Mother's age (years) & $28.0 \pm 6.4$ & $29.7 \pm 7.0$ \\
\hline
\end{tabular}

Table 2. The distribution of the infant mortality reasons

\begin{tabular}{lcccccc} 
& \multicolumn{2}{c}{$\mathbf{2 0 1 6}$} & & \multicolumn{2}{c}{$\mathbf{2 0 1 7}$} \\
\cline { 2 - 3 } \cline { 7 - 7 } Causes of Death & $\mathbf{n}$ & $\mathbf{\%}$ & & $\mathbf{n}$ & $\%$ \\
\hline Prematurity & 43 & 43.4 & & 25 & 37.3 \\
Congenital Anomaly & 35 & 35.4 & & 28 & 41.7 \\
Perinatal Asphyxia & 5 & 5.1 & & 4 & 6.0 \\
Infection & 4 & 4.0 & & 2 & 3.0 \\
Gastroenteritis & 2 & 2.0 & & 0 & 0.0 \\
Preeclampsia & 1 & 1.0 & & 0 & 0.0 \\
House Accident & 2 & 2.0 & & 0 & 0.0 \\
Sudden Infant Dead Syndrome & 1 & 1.0 & & 4 & 6.0 \\
Postoperative Complication & 1 & 1.0 & & 0 & 0.0 \\
Hydrops Fetalis & 0 & 0.0 & & 1 & 1.5 \\
Unknown & 5 & 5.1 & & 3 & 4.5 \\
Total & 99 & 100.0 & & 67 & 100.0
\end{tabular}


Table 3. Infant mortality of Bingöl for the year 2016- 2017

\begin{tabular}{|c|c|c|c|c|}
\hline Distributions by Days of Death & $\begin{array}{l}2016 \\
\text { n (\%) }\end{array}$ & $\begin{array}{l}2017 \\
\text { n (\%) }\end{array}$ & $x^{2}$ & $\mathbf{p}$ \\
\hline Early neonatal infant mortality (0-7 days) & $52(52.5)$ & $30(44.8)$ & 5.8 & 0.016 \\
\hline Post-neonatal infant mortality (29-365 days) & $39(39.4)$ & $21(31.3)$ & 4.7 & 0.030 \\
\hline Total & $99(100.0)$ & $67(100.0)$ & 6.0 & 0.014 \\
\hline
\end{tabular}

neonatal period was not statistically significant $(p=0.016$, $p=0.030$ and $p=0.147$, respectively) (Table 3 ).

\section{DISCUSSION}

In our study, we revealed the speed and descriptive characteristics of infant deaths in 2016 and 2017 in Bingöl province. The infant mortality rate decreased from 18 per thousand to 12.3 per thousand within one year. The decline in congenital anomalies was less, as a significant part of this decline was the result of diminished deaths from prematurity.

In 2016, the infant mortality rate in Bingöl province was measured as 18.0 per thousand. The most common causes of death were prematurity and congenital anomaly. Causes of death were preventable. It was observed that infant mortality was above the average rates of the region and country in 2016. Thus, field intervention was planned except for the routine monitoring and evaluation of the ministry of health. Control and training were organized to examine the causes of infant mortality and to improve infant and pregnant follow-up in primary care. The planned interventions were applied at the beginning of 2017. To eliminate the deficiencies in the detection of pregnancy, notifications were made to the family physicians of the women who were diagnosed with pregnancy in the health institutions, and it was checked whether or not the primary care follow-up was performed. A total of four training was provided to the family doctors and family healthcare employees to increase the awareness of infant mortality, the reasons for infant mortality, and what should be done to avoid it. It was ensured that each pregnant woman and infants were followed and registered with a standard form. Then, audits were made at certain times; and it was ensured that missing services were compensated. The forms made for follow up the infants and pregnant women were checked over the Ministry of Health database to confirm whether the forms were correctly filled out by the doctors. We think that awareness increases in healthcare workers through training and controls. In this study, the effectiveness of interventions could not be measured. There are other factors (social variables, secondary health care) that may affect infant mortality. How primary care followup changes after intervention could not be measured. Although it has been observed by the researchers that the intervention is effective in the field for improving the primary level follow-up, we do not have objective data on the effectiveness of the intervention.

According to the results of the World Health Organization (WHO) 2016 health statistics, a total of 5.9 million deaths occur under the age of 5 worldwide; and 2.7 million of these are newborns. The rate of infant mortality for those under the age of 5 was 42.5 per thousand, and the rate of neonatal deaths was 19 per thousand. ${ }^{[4]}$ According to the 2013 Turkey Demographic and Health Survey data, the infant mortality rate was 13 per thousand in Turkey; and according to the Turkish Statistical Institute (TUIK) 2016 data, the infant mortality rate was 10 per thousand across Turkey. Similarly, according to the TUIK data, the infant mortality rate was 13.7 per thousand in the Middle Eastern Anatolian region, where the city of Bingöl is included. ${ }^{[3,5]}$

The infant mortality rate in the eastern regions of Turkey seems to be higher than the country's average ${ }^{[3]}$ Regionally different health data in the country can be attributed to that the eastern region is underdeveloped from the west concerning socioeconomic aspects, and the fertility rate in the east is higher than in the west. While the rate is 3.4 in the east, the total fertility rate is 1.9 in the west. In addition, the rates of infant and pregnant follow-up were lower in the eastern region than in the western regions. ${ }^{[3]}$ In a study conducted in Turkey's western city examining 2006 and 2007 infant deaths, infant mortality rates were found in 10.7 and 10.1 per thousand, respectively. ${ }^{[6]}$ In this western city, the infant mortality rate was 10.7 per thousand in 2006, while in Bingöl province, it was 18 per thousand in 2016 and 13.2 in 2017. This may be due to the regional socioeconomic difference Given that Bingöl province is in the $72^{\text {nd }}$ place among 81 provinces in the socioeconomic development ranking. ${ }^{[7]}$ 
According to WHO data, the three major causes of neonatal deaths worldwide are infections (36\%, which include sepsis/ pneumonia, tetanus and diarrhea), pre-term (28\%), and birth asphyxia (23\%). ${ }^{[8]}$ In our study, two deaths were observed in 2016 due to diarrhea, but no death was observed in 2017. In studies on infant mortality in Turkey, the proportion of deaths due to infection seems to be lower compared to other causes. ${ }^{[6,9,10]}$ This can be attributed to the increase in the general level of development in the country and the effectiveness of the practices, such as vaccination program, water sanitation, applied in Turkey. Between the years 19902017, Turkey's HDI value increased from 0.579 to 0.791 . Between 1990 and 2017, life expectancy 11.7 years; the average duration of education 3.5 years increased, in per capita Gross National Product ratio showed an increase of approximately $121.2 \%$ between 1990 to 2017 years. ${ }^{[1]}$ The cause of infant death in the studies conducted in Turkey, we see that prematurity and congenital anomalies as reasons in the first two rows. In the study examining 2008 infant deaths in Sakarya, a western city of Turkey, the first cause of infant mortality was prematurity, ${ }^{[10]}$ while in the study examining 2006 infant deaths in Kayseri, a central zone city, the first cause of infant mortality was a congenital anomaly. ${ }^{[12]}$

According to the 2015 data, on the other hand, the most common causes of neonatal mortality worldwide were prematurity and birth-related complications. The infant mortality causes in the post-neonatal period were mostly pneumonia, injuries, malaria and diarrhea. ${ }^{[4]}$ In our study, similarly, most of the deaths occurred in the early neonatal period; and the most common cause of mortality was prematurity and congenital anomalies. It is seen that mortality rates related to premature were more before the intervention made in the field, and it is also seen that the mortality rates related to prematurity and congenital anomalies decreased in number after the intervention.

In a study that compared infant mortality in the UK and Switzerland in Western Europe, the findings showed that the mortality rate for infants below the age of 5 was 4.9 per thousand in the UK. This rate is one of the highest mortality rates in the Western European region. The rate of death in Switzerland was reported as 2.7. ${ }^{[13]}$ Early, late and postneonatal infant mortality rates were found to be higher in the UK than in Switzerland. Mortality due to congenital anomaly and prematurity were found to be higher in the UK. The birth characteristics were shown as the biggest explanatory variable for the 2-27-day-old infant mortality in the UK is more than in Switzerland. Also, 3\% of the infant mortality was associated with socioeconomic reasons. For the purpose of reducing infant mortality rates in the UK, it was concluded that the prevalence of low birth weight, prematurity, congenital anomalies should be reduced. It was also reported that socioeconomic status contributed less to infant mortality (10\%). ${ }^{[14]}$ In our study, the reason for the infant mortality rate being over 10 per thousand in Bingöl province is that the socioeconomic development of the middle Anatolian eastern region and Turkey is lower from the Western European countries. The existence of infant mortality reasons other than congenital anomaly and prematurity explain the high rates in infant mortality.

In an intervention study in Pakistan, female health employees were trained, and these employees were provided with a "Home Bag" that was provided for resuscitation purposes, and oral amoxicillin support was provided to treat pneumonia and other serious infections. The trained female healthcare providers paid visits to women who gave birth and to newborns. It was observed that the neonatal mortality decreased by $20 \%$ in the Intervention Group. ${ }^{[15]}$ Our study, on the other hand, included an intervention for family doctors and assistant health staff, who worked mostly on the field. A total of 4 training was provided to the family doctors to increase the awareness of infant mortality, the reasons for infant mortality, and what should be done to avoid infant mortality. It is ensured that each pregnant woman was followed and registered with a standard form. Then, audits were made at certain times; and it was ensured that missing services were compensated. When compared with the previous year, a numerical decrease occurred in all mortality reasons.

In our study, it has not been possible to measure how well the baby and pregnant scans were improved after the controls and training. We can state this as a limitation of our research. No research funding has been received from any institution, and there is no conflict of interest of the authors.

\section{CONCLUSION}

In our study, infant mortality rates in Bingöl were higher than the national average in 2016 and 2017. Congenital anomaly and prematurity were the most common causes of infant mortality in both years. Such studies showing the causes of infant mortality and their changes over the years can be a guide for health policymakers.

\section{Disclosures}

Peer-review: Externally peer-reviewed.

Conflict of Interest: None declared.

Ethics Committee Approval: This study was approved by the Ethics Committee with the letter No. 23234772-929 and dated 17.12.2019 of Bingöl Provincial Health Directorate. 
Authorship Contributions: Concept - S.Y., B.M., V.S.; Design S.Y., B.M. V.S.; Supervision - S.Y., B.M., V.S.; Materials - S.Y., B.M., V.S.; Data collection \&/or processing - S.Y., B.M.; Analysis and/or interpretation - S.Y., B.M.; Literature search - S.Y., B.M.; Writing S.Y., B.M., V.S., E.P.; Critical review - E.P.

\section{REFERENCES}

1. Tezcan S, Türkiye'de bebek ve çocuk ölümleri. Hacettepe Üniversitesi Tıp Fakültesi Halk Sağlığı Anabilim Dalı Yayınları 1985.

2. Eryurt MA, Koç İ. Yoksulluk ve çocukölümlülüğü: Hane halkı refah düzeyinin çocuk ölümlülüğü üzerindeki etkisi. Çocuk Sağlığı ve Hastalıkları Dergisi 2009;52:113-21.

3. Hacettepe University Institute of Population Studies. Turkey Population and Health Survey 2013. Available at: http://www. hips.hacettepe.edu.tr/tnsa2013/rapor/TNSA_2013_ana_ rapor.pdf. Accessed Feb 17, 2020.

4. Türkiye İstatistik Kurumu haber bülteni, Ölüm İstatistikleri 2016. Available at: http://www.tuik.gov.tr/PreHaberBultenleri. do?id=24649. Accessed Feb 17, 2020.

5. Levels \& Trends in Child Mortality. Report 2015. Available at: https://www.unicef.org/media/files/IGME_report_2015_ child_mortality_final.pdf. Accessed Feb 17, 2020.

6. Karabulut A, İstanbullu B, Karahan T, Özdemir K. Two year evaluation of infant and maternal mortality in Denizli. Sepsis 2009;3(3):12.

7. Kalkınma Bakanlığı. İllerin ve bölgelerin sosyo-ekonomik gelişmişlik sıralaması araştırması (sege-2011) (internet) 2013; (cited 2019 february 14) Available from: http://www3.kalkinma.gov.tr/DocObjects/View/15310/SEGE-2011.pdf

8. 2005 World Health Report: Make Every Mother and Child
Count. Available at: https:/www.who.int/whr/2005/ whr2005_en.pdf. Accessed Feb 17, 2020.

9. Alkan A, Elevli M, Ataoğlu E, Şahin K, Büyükkayhan D, Selçuk Duru $\mathrm{H}$, et al. Haseki eğitim ve araştırma hastanesinde doğan bebeklerin morbidite ve mortalite nedenleri açısından üç yıllık retrospektif değerlendirilmesi. Med Bull Haseki 2016;54(3):161-5. [CrossRef]

10. Demir F, Onsuz MF, Catalbas Y. Evaluation of infant mortality rate in Sakarya province in 2008: A Cross-Sectional Study. Nobel Medicus 2015;11(2):59-64.

11. Human Development Indices and Indicators: 2018 Statistical Update Briefing note for countries on the 2018 Statistical Update Turkey (internet) 2008 (cited 2019 february 14) Available from:http://hdr.undp.org/sites/all/themes/hdr_theme/ country-notes/TUR.pdf

12. Balcı E, Küçük E, Gün İ, Gülgün M, Kılıç B, Çetinkara K. Kayseri Ili Melikgazi İlçesinde 2006 yılında meydana gelen bebek ölümleri. Fırat Üniv Sağlık Bilimleri Derg 2008;22:323-6.

13. Wang $H$, Liddell CA, Coates MM, Mooney MD, Levitz CE, Schumacher $A E$, et al. Global, regional, and national levels of neonatal, infant, and under-5 mortality during 1990-2013: a systematic analysis for the Global Burden of Disease Study 2013. Lancet 2014;384(9947):957-79. [CrossRef]

14. Zylbersztejn A, Gilbert R, Hjern A, Wijlaars L, Hardelid P. Child mortality in England compared with Sweden: a birth cohort study. Lancet 2018;391(10134):2008-18. [CrossRef]

15. Soofi S, Cousens S, Turab A, Wasan Y, Mohammed S, Ariff S, et al. Effect of provision of home-based curative health services by public sector health-care providers on neonatal survival: a community-based cluster-randomised trial in rural Pakistan. Lancet Glob Health 2017;5(8):e796-e806. [CrossRef] 